\title{
Processing of Caustic Calcined Magnesite (Magnesium Oxide) by the Use of Triboelectrostatic Belt Separation
}

\author{
Sabrina Gehringer ${ }^{1}$, Christoph Luckeneder ${ }^{1}$, Frank Hrach ${ }^{2}$, and Helmut Flachberger ${ }^{1}$ \\ ${ }^{1}$ Chair of Mineral Processing, Department Mineral Resources Engineering, Montanuniversität Leoben, Leoben, \\ Austria \\ ${ }^{2}$ ST Equipment \& Technology LLC, Needham, USA
}

Received June 24, 2019; accepted June 25, 2019; published online July 15, 2019

\begin{abstract}
In this study, several tests were examined to analyze the sortability of magnesium oxide $(\mathrm{MgO})$ by the use of triboelectrostatic belt separation. The objective of the study is to find a dry sorting technique to separate $\mathrm{MgO}$ from accompanying components such as $\mathrm{CaO}$ and $\mathrm{SiO}_{2}$. The aim of this first series of experiments was to develop knowledge about the triboelectrostatic charging behaviour of magnesium oxide. All sorting tests were carried out by the use of a triboelectrostatic belt separator in lab scale in an air-conditioned room.
\end{abstract}

Keywords: Electrostatic separation, Mineral processing, Caustic calcined magnesite, Magnesium oxide, Dry processing methods

Sortierung von kaustisch gebranntem Magnesit (Magnesiumoxid) mittels triboelektrostatischer Bandscheidung

Zusammenfassung: Im Rahmen dieser Studie wurden mehrere Versuchsreihen durchgeführt, um die Sortierbarkeit von ofenfallendem Magnesiumoxid ( $\mathrm{MgO}$ ) unter Verwendung der triboelektrostatischen Bandscheidung zu analysieren. Ziel der Studie ist es, ein trockenes Sortierverfahren zu finden, um die Begleitkomponenten wie $\mathrm{CaO}$ und $\mathrm{SiO}_{2}$ des $\mathrm{MgO}$-Produktes möglichst vollständig abzutrennen. Ziel dieser ersten Versuchsreihe war es, Erkenntnisse über das triboelektrostatische Aufladeverhalten der enthaltenen Mineralphasen zu gewinnen. Alle Sortierversuche wurden mit einem triboelektrostatischen Bandabscheider im Labormaßstab in einem klimatisierten Raum durchgeführt.

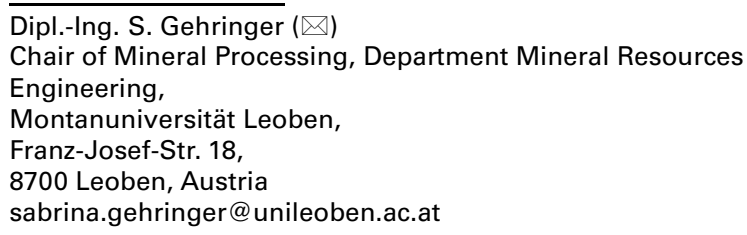

Schlüsselwörter: Elektrostatische Sortierung, Mineralaufbereitung, Kaustisch gebrannter Magnesit, Magnesiumoxid, Trocken-Sortierverfahren

\section{Introduction}

Magnesium oxide $(\mathrm{MgO})$ is one of the most important products of the refractory industry. It is usually produced by thermal decomposition of magnesite $\left(\mathrm{MgCO}_{3}\right)$ or by a seawater process from magnesium hydroxide $\left(\mathrm{Mg}(\mathrm{OH})_{2}\right)$ [1].

The type of raw material, the temperature of calcination and the impurities mostly affect the physical properties of $\mathrm{MgO}[2,3]$.

Caustic calcined $\mathrm{MgO}$ is burned at temperatures below $900^{\circ} \mathrm{C}$. It is used in fertilizers, as animal feed and as a raw material for various $\mathrm{MgO}$ chemicals for the production of pulp and paper, ceramics and cements.

A characteristic property of this $\mathrm{MgO}$ type is its moderate to high chemical reactivity [1].

Because of this reactivity, it is imperative to search for a dry processing technique for the enrichment of the $\mathrm{MgO}$, lest a transformation to $\mathrm{Mg}(\mathrm{OH})_{2}$ take place which influences the product in an undesirable way.

\section{Separation Process}

One such dry process is electrostatic separation, a surface controlled process.

The separation features in the electrostatic field is the different size or opposite charge of the grain surfaces. These charge differences are generated by the so-called tribo-polarization.

If there is an electron transfer between the contact partners, they receive opposite surface charges. The intensity of this electron transfer depends on the size of the contact surface as well as the contact duration, frequency and strength. The charging mechanism is activated by intense 
Fig. 1: Operation principle of a triboelectrostatic belt separator [7]

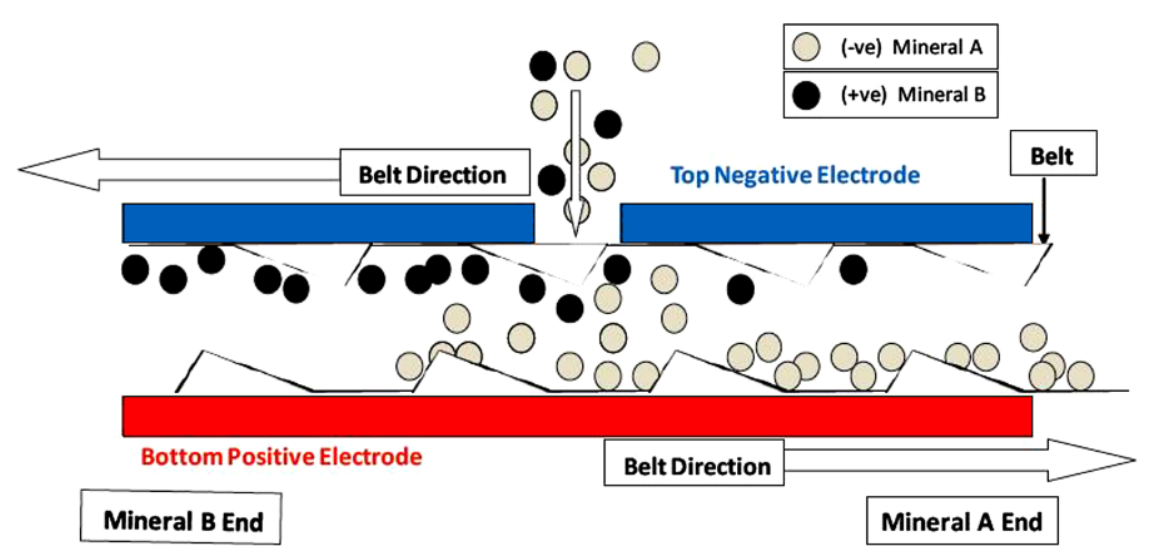

grain/grain contact and grain/wall contact. Often this is realized in upstream units which are not involved in the separation process itself, for example by the use of vibro feeders, fluid bed dryers or cyclones [4-6].

The operation principle of a triboelectrostatic belt separator is shown in Fig. 1; [7].

\section{Influence on the Charging Mechanism}

In this research, the charging behaviour of the magnesium oxide surfaces is studied to check the possibility of a successful separation in the electrostatic field. On the basis of systematic parameter studies, triboelectrostatic charging mechanisms are examined in detail in order to conduct the charging in a controlled manner. The targeted triboelectrostatic charging of mineral surfaces is intended to expand the range of applications of electro-separation within dry industrial mineral processing.

Electrostatic separation is a surface controlled process, this offers the possibility of selectively changing the surface states by means of raw material pre-treatment. In the present work the influence of variation of the raw material temperature was tested $[4,5,7]$.

Furthermore, the machine settings at the triboelectrostatic belt separator were tested to find the optimum setting for the separation of the $\mathrm{MgO}$.

\section{Characterization of the MgO Sample}

To obtain a first impression of the mineral phase distribution in the particle size classes, a sieve analysis was carried out and the chemical composition was determined in the produced fractions.

The particle size distribution of the feed sample is summarized in Table 1 and Fig. 2.

Table 2 and Fig. 3 show the chemical composition in the particle size classes. The $\mathrm{MgO}$ content increases with decreasing grain size, the two accompanying constituents $\mathrm{CaO}$ and $\mathrm{SiO}_{2}$ show a common trend.

\begin{tabular}{|llll}
\hline \multicolumn{4}{|l|}{$\begin{array}{l}\text { TABLE } \\
\text { Particle size }\end{array}$} \\
\hline Mesh & Yield & Residual & Passing \\
\hline$\mu \mathrm{m}$ & $\%$ & $\%$ & $\%$ \\
\hline$>100$ & 13.20 & 13.20 & 86.80 \\
\hline $100 / 63$ & 26.73 & 39.93 & 60.07 \\
\hline $63 / 40$ & 19.86 & 59.79 & 40.21 \\
\hline $40 / 0$ & 40.21 & 100.00 & 0.00 \\
\hline
\end{tabular}

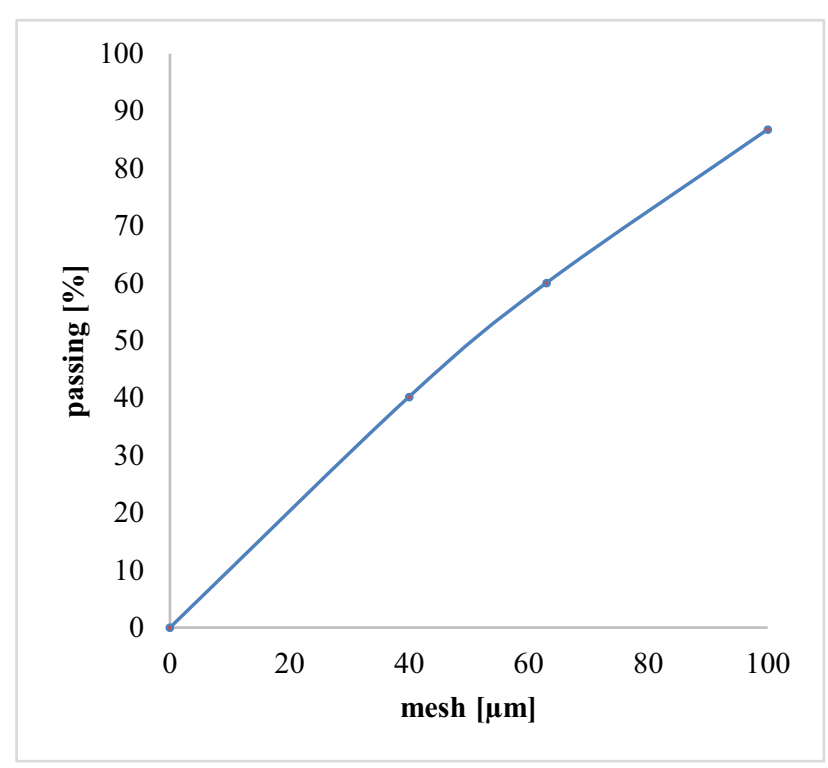

Fig. 2: Particle size distribution of the feed in linear grid

\section{Experimentation}

\subsection{Experimental Design}

The experimental design is based on the statistical design of experiments, which is a further development of traditional experimental design methods. Through detailed 


\begin{tabular}{|llll|}
\hline $\begin{array}{l}\text { TABLE 2 } \\
\text { Chemical composition }\end{array}$ & in the particle size classes \\
\hline Mesh & $\mathrm{MgO}$ & $\mathrm{CaO}$ & $\mathrm{SiO}_{2}$ \\
\hline$\mu \mathrm{m}$ & $\%$ & $\%$ & $\%$ \\
\hline$>100$ & 51.25 & 20.06 & 9.15 \\
\hline $100 / 63$ & 75.15 & 7.38 & 5.07 \\
\hline $63 / 40$ & 83.48 & 4.37 & 2.93 \\
\hline $40 / 0$ & 85.77 & 3.63 & 2.86 \\
\hline
\end{tabular}

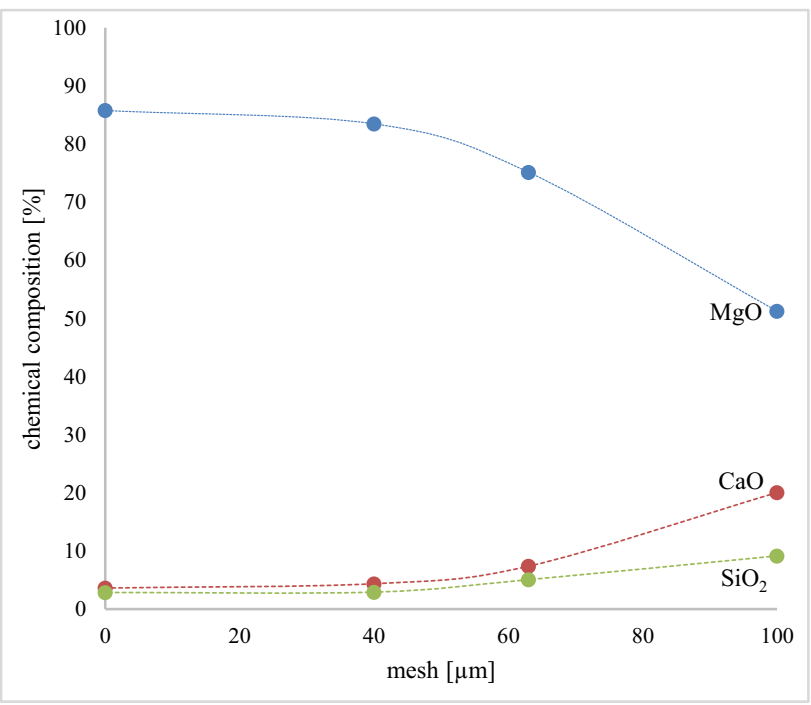

Fig. 3: Chemical composition in the particle size classes

planning and targeted change of influencing factors, the efficiency of the experimental setup can be increased [8].

\subsection{Triboelectrostatic Belt Separator}

The experiments were carried out on a lab scale triboelectrostatic belt separator. For the operational principle, cf. Fig. 1. The feed passes from above via a vibrating unit into the separation area with electrodes arranged one above the other. The polarity of the electrodes can be reversed on both sides. Product discharge takes place on the left and right side of the stripper after leaving the separation chamber. The two products are collected in plastic bags.

\subsection{Influence of Machine Parameters}

The lab scale belt separator enables the variation of numerous parameters. In order to gain knowledge about the influence of these parameters on the charging behaviour of $\mathrm{MgO}$, these and their interactions with each other were analyzed. For the execution of the experiments, a partial factorial design of type "2 $2^{5-1 "}$ was chosen [8]. The separation success was assessed by determining the chemical composition by means of RFA.

The following machine parameters can be changed on the lab scale belt separator:
a) applied voltage
b) electrode distance
c) belt speed
d) polarity of the top electrode
e) feed rate
f) belt geometry

Ad a) The voltage applied to the electrodes can be infinitely adjusted from 0 to $6 \mathrm{kV}$. For the tests, the levels for the applied voltage were set at 3 and $6 \mathrm{kV}$.

Ad b) The electrode distance is limited by the geometric conditions. For the maximum distance a value of $14 \mathrm{~mm}$ is determined, for the minimum it is $9 \mathrm{~mm}$. These two extremes are taken as a level in the experimental design plan.

Ad c) A belt speed of $36 \mathrm{fps}(11 \mathrm{~m} / \mathrm{s})$ is defined as the upper level in the design plan. For the lower level $17 \mathrm{fps}$ are selected.

Ad d) The polarity of the top and bottom electrode can be set positive or negative. One electrode must always be positive and one negative for the generation of an electrostatic field. For the experiments, both variants were implemented. Further information on the polarity always refer to the head electrode.

Ad e) The feed rate of the vibro unit can be adjusted from 1 to 10 . The values 5 and 10 are defined as levels.

Ad f): This parameter is not included in the experimental design plan. For the entire series of experiments, the geometry of the band remains unchanged.

The parameters a) to e) given here were taken over into a partial factorial design of the type " $2^{5-1 " ~[7] . ~}$

\subsection{Experimental Setup}

During the setup of the experiments, the machine settings were changed as previously defined in the design plan. The exterior influences of the system were kept constant as far as possible. Such influences are ambient temperature and relative humidity. The room temperature during the experiment was about $25^{\circ} \mathrm{C}$, the relative humidity about $20 \%$. At the first tests, the magnesia was processed at ambient temperature.

\subsection{Optimum Machine Parameters}

The assessment of the influence of the machine parameters was carried out by the average values of the $\mathrm{MgO}, \mathrm{CaO}$ and $\mathrm{SiO}_{2}$ content in the concentrate and the mass output of concentrate at the different settings. The average values were always calculated from the results obtained at the different levels, from the two mean values at setting (maximum) and (minimum) the difference between these two values was also formed, which describes the intensity of the influence of the factor. For all other tests that do not relate to a further optimization of the machine parameters, the optimum machine settings are used from now on. 


\begin{tabular}{|lllllll}
\hline \multicolumn{7}{|l}{$\begin{array}{l}\text { TABLE } \\
\text { Particle size distribution of the tailings and chemical composition in the classes }\end{array}$} \\
\hline Mesh & Yield & Residual & Passing & MgO & $\mathrm{CaO}$ & $\mathrm{SiO}_{2}$ \\
\hline$\mu \mathrm{m}$ & $\%$ & $\%$ & $\%$ & $\%$ & $\%$ & $\%$ \\
\hline$>100$ & 12.46 & 12.46 & 87.54 & 52.55 & 19.80 & 8.45 \\
\hline $100 / 63$ & 33.99 & 46.46 & 53.54 & 77.66 & 6.49 & 4.27 \\
\hline $63 / 40$ & 15.86 & 62.32 & 37.68 & 83.26 & 4.38 & 2.94 \\
\hline $40 / 0$ & 37.68 & 100.00 & 0.00 & 85.67 & 3.57 & 2.99 \\
\hline
\end{tabular}

\begin{tabular}{|c|c|c|c|c|c|c|}
\hline Mesh & Yield & Residual & Passing & $\mathrm{MgO}$ & $\mathrm{CaO}$ & $\mathrm{SiO}_{2}$ \\
\hline$\mu \mathrm{m}$ & $\%$ & $\%$ & $\%$ & $\%$ & $\%$ & $\%$ \\
\hline$>100$ & 14.09 & 14.09 & 85.91 & 49.67 & 20.37 & 10.01 \\
\hline $100 / 63$ & 17.87 & 31.96 & 68.04 & 72.09 & 8.47 & 6.04 \\
\hline $63 / 40$ & 24.74 & 56.70 & 43.30 & 83.73 & 4.36 & 2.91 \\
\hline $40 / 0$ & 43.30 & 100.00 & 0.00 & 85.90 & 3.69 & 2.70 \\
\hline
\end{tabular}

\subsection{Particle Size Distribution of the Products}

Tables 3 and 4 and Fig. 4 show the particle size distribution of concentrate and tailings. The tailings have a coarser particle size distribution than the concentrate. In both products, the contents of $\mathrm{MgO}$ is largest in the finest fraction and the contents of $\mathrm{CaO}$ and $\mathrm{SiO}_{2}$ are largest in the coarsest fraction.

\subsection{Division Number}

In the grain size classes obtained by the sieve analysis, a chemical analysis was carried out. From these results the partition numbers in the grain size classes were calculated. The partition number indicates the fraction, which has arrived from product class " $\mathrm{i}$ " present in the task in the

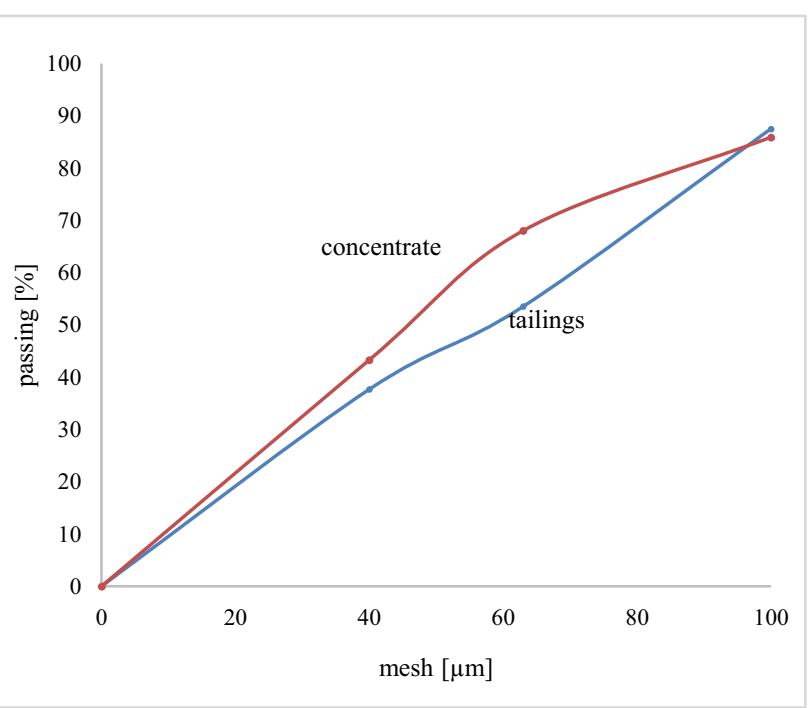

Fig. 4: Particle size distribution of the products in linear grid final product " $\mathrm{j}$ ". This calculation was realized according to the Eq. 1:

$$
T=\frac{r m j * m \mu j}{m \mu 0}
$$

$T \mu j \ldots \quad$ partition number of property class $\mu$ in relation to the product $j$

$r m j \ldots \quad$ mass yield of product $j$

$m \mu j \ldots \quad$ mass fraction of feature class $\mu$ in product $j$

$m \mu 0 \ldots$ mass fraction of feature class $\mu$ in the feed

The concentrate-related partition curves for $\mathrm{MgO}, \mathrm{CaO}$ and $\mathrm{SiO}_{2}$ are shown in Figs. 5, 6 and 7. The highest contents of $\mathrm{MgO}, \mathrm{CaO}$ and $\mathrm{SiO}_{2}$ were determined in the particle size class $63 / 40 \mu \mathrm{m}$. The concentrate-related partition number for $\mathrm{MgO}$ in this fraction was calculated with $56.3 \%$. For

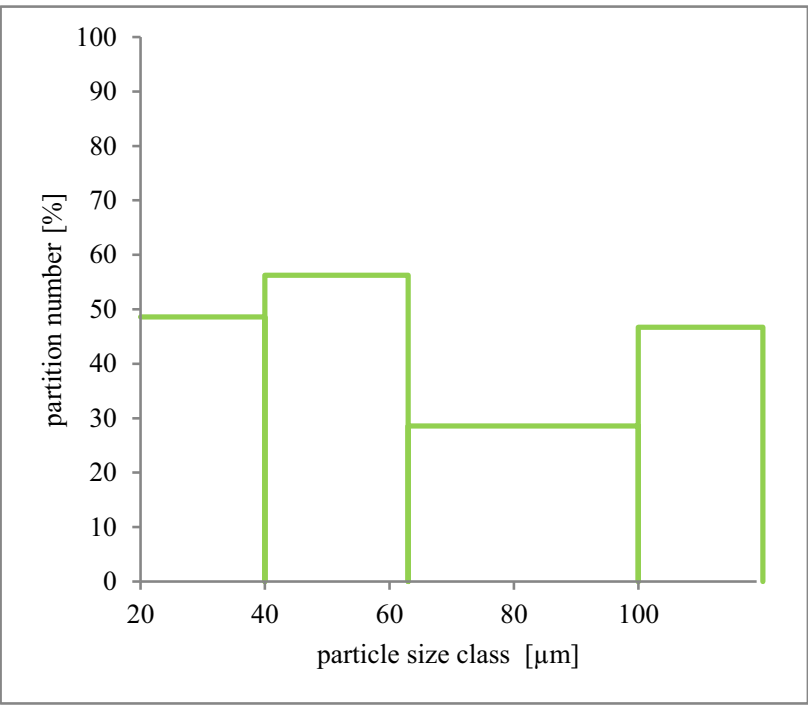

Fig. 5: Concentrate related partition number $-\mathrm{MgO}$ grade 


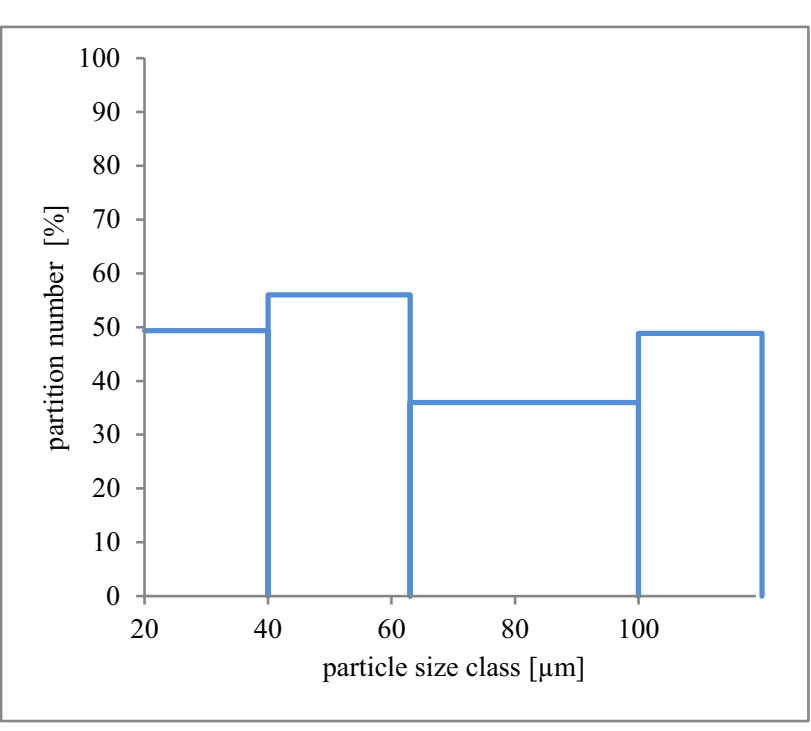

Fig. 6: Concentrate related partition number $-\mathrm{CaO}$ grade

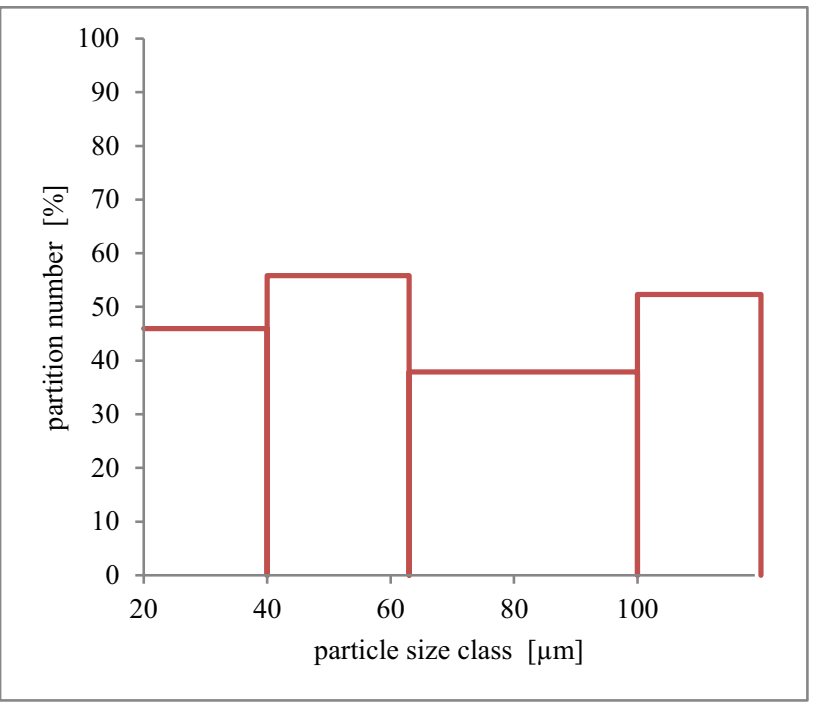

Fig. 7: Concentrate related partition number $-\mathrm{SiO}_{2}$ grade
$\mathrm{CaO}$ and $\mathrm{SiO}_{2}$, similarly high partition numbers in the same particle size classes were calculated with 56.0 and $55.8 \%$.

\subsection{Feed Temperature}

To investigate the influence of the feed temperature, the magnesium oxide samples were preheated at $80^{\circ} \mathrm{C}$ in a drying oven. Due to manipulation, this corresponds approximately to an application temperature of about $65^{\circ} \mathrm{C}$. This temperature also corresponds to the maximum temperature that can be sorted at the belt separator without causing merging between raw material and the polymer belt. The results for the influence of the raw material temperature on the charging behaviour of magnesium oxide are summarized in Table 5. The triboelectrostatic charging efficiency decreased compared to the experiments in which the feed was sorted at room temperature. The increase in temperature had a negative effect on all areas except the content of $\mathrm{CaO}$. This increased in the tailings product and decreased in the concentrate. However, this effect is due to the general lower efficiency of the triboelectrostatic charging behaviour.

\subsection{Belt Speed}

The orbital speed of the belt was identified as the main influencing factor in the test series for determining the optimum machine parameters. For this reason, the belt speed was examined in more detail. The recovery and the grades $\left(\mathrm{MgO}, \mathrm{CaO}\right.$ and $\left.\mathrm{SiO}_{2}\right)$ of the concentrate are summarized in Table 6 and visualized in the Figs. 8, 9 and 10.

Figure $8 \mathrm{a}, \mathrm{b}$ show that the $\mathrm{MgO}$ grade and the yield over the belt speed. Both values reach their maximum at a belt speed of about $36 \mathrm{fps}$ ( $11 \mathrm{~m} / \mathrm{s})$.

The yield and the grade of $\mathrm{SiO}_{2}$ are also in a favorable range at a belt speed of $36 \mathrm{fps}(11 \mathrm{~m} / \mathrm{s})$ (Fig. 9a, b).

Figure $10 \mathrm{a}, \mathrm{b}$ show $\mathrm{CaO}$ grade and the yield over the belt speed. At a speed of $36 \mathrm{fps}$, the $\mathrm{CaO}$ yield reaches a value of $87.7 \%$ which is near the maximum. This fact influences the concentrate quality in an undesirable way.

\begin{tabular}{|c|c|c|c|c|c|c|c|c|}
\hline \multirow{2}{*}{$\begin{array}{l}\text { Feed } \\
\text { temperature }\end{array}$} & \multirow[t]{2}{*}{ Product } & \multirow{2}{*}{$\begin{array}{l}\text { Mass yield } \\
\text { [\%] }\end{array}$} & \multicolumn{2}{|l|}{$\mathrm{SiO}_{2}$} & \multicolumn{2}{|l|}{$\mathrm{CaO}$} & \multicolumn{2}{|l|}{$\mathrm{MgO}$} \\
\hline & & & $\begin{array}{l}\text { Grade } \\
{[\%]}\end{array}$ & $\begin{array}{l}\text { Recovery } \\
{[\%]}\end{array}$ & $\begin{array}{l}\text { Grade } \\
{[\%]}\end{array}$ & $\begin{array}{l}\text { Recovery } \\
\text { [\%] }\end{array}$ & $\begin{array}{l}\text { Grade } \\
{[\%]}\end{array}$ & $\begin{array}{l}\text { Recovery } \\
{[\%]}\end{array}$ \\
\hline \multirow[t]{3}{*}{$65^{\circ} \mathrm{C}$} & Tailings & 59.79 & 3.43 & 63.72 & 5.01 & 59.35 & 81.79 & 59.62 \\
\hline & Concentrate & 40.21 & 2.91 & 36.28 & 5.10 & 40.65 & 82.37 & 40.38 \\
\hline & Feed & 100.00 & 3.22 & 100.00 & 5.05 & 100.00 & 82.02 & 100.00 \\
\hline \multirow[t]{3}{*}{$25^{\circ} \mathrm{C}$} & Tailings & 16.16 & 13.42 & 77.43 & 3.89 & 12.88 & 74.70 & 14.53 \\
\hline & Concentrate & 83.84 & 0.39 & 11.57 & 5.10 & 87.70 & 85.01 & 85.77 \\
\hline & Feed & 100.00 & 2.80 & 100.00 & 4.87 & 100.00 & 83.10 & 100.00 \\
\hline \multirow{2}{*}{$\begin{array}{l}\text { Difference } \\
{[\%]}\end{array}$} & Tailings & 43.63 & - & -13.71 & - & 46.46 & - & 45.09 \\
\hline & Concentrate & -43.63 & - & 24.71 & - & -47.05 & - & -45.39 \\
\hline
\end{tabular}




\begin{tabular}{|c|c|c|c|c|c|c|c|c|}
\hline Belt speed & Product & Mass yield & $\mathrm{SiO}_{2}$ & & $\mathrm{CaO}$ & & $\mathrm{MgO}$ & \\
\hline \multirow[t]{2}{*}{ [fps] } & & & Grade & Recovery & Grade & Recovery & Grade & Recovery \\
\hline & & [\%] & [\%] & [\%] & [\%] & [\%] & [\%] & [\%] \\
\hline \multirow[t]{3}{*}{12} & Tailings & 19.17 & 13.25 & 79.03 & 3.27 & 12.72 & 76.21 & 17.68 \\
\hline & Concentrate & 80.83 & 0.83 & 20.97 & 5.31 & 87.28 & 84.12 & 82.32 \\
\hline & Feed & 100.00 & 3.21 & 100.00 & 4.92 & 100.00 & 82.61 & 100.00 \\
\hline \multirow[t]{3}{*}{20} & Tailings & 24.14 & 11.33 & 88.10 & 3.55 & 17.27 & 77.59 & 22.65 \\
\hline & Concentrate & 75.86 & 0.49 & 11.90 & 5.41 & 82.73 & 84.33 & 77.35 \\
\hline & Feed & 100.00 & 3.10 & 100.00 & 4.96 & 100.00 & 82.71 & 100.00 \\
\hline \multirow[t]{3}{*}{28} & Tailings & 18.52 & 12.79 & 89.35 & 3.98 & 14.51 & 75.11 & 16.78 \\
\hline & Concentrate & 81.48 & 0.35 & 10.65 & 5.34 & 85.49 & 84.69 & 83.22 \\
\hline & Feed & 100.00 & 2.65 & 100.00 & 5.08 & 100.00 & 82.91 & 100.00 \\
\hline \multirow[t]{3}{*}{36} & Tailings & 16.16 & 13.42 & 77.43 & 3.89 & 12.88 & 74.70 & 14.53 \\
\hline & Concentrate & 83.84 & 0.39 & 11.57 & 5.10 & 87.70 & 85.01 & 85.77 \\
\hline & Feed & 100.00 & 2.80 & 100.00 & 4.87 & 100.00 & 83.10 & 100.00 \\
\hline \multirow[t]{3}{*}{44} & Tailings & 16.91 & 15.75 & 90.58 & 3.62 & 11.72 & 72.63 & 14.94 \\
\hline & Concentrate & 83.09 & 0.33 & 9.42 & 5.55 & 88.28 & 84.18 & 85.06 \\
\hline & Feed & 100.00 & 2.94 & 100.00 & 5.23 & 100.00 & 82.23 & 100.00 \\
\hline
\end{tabular}
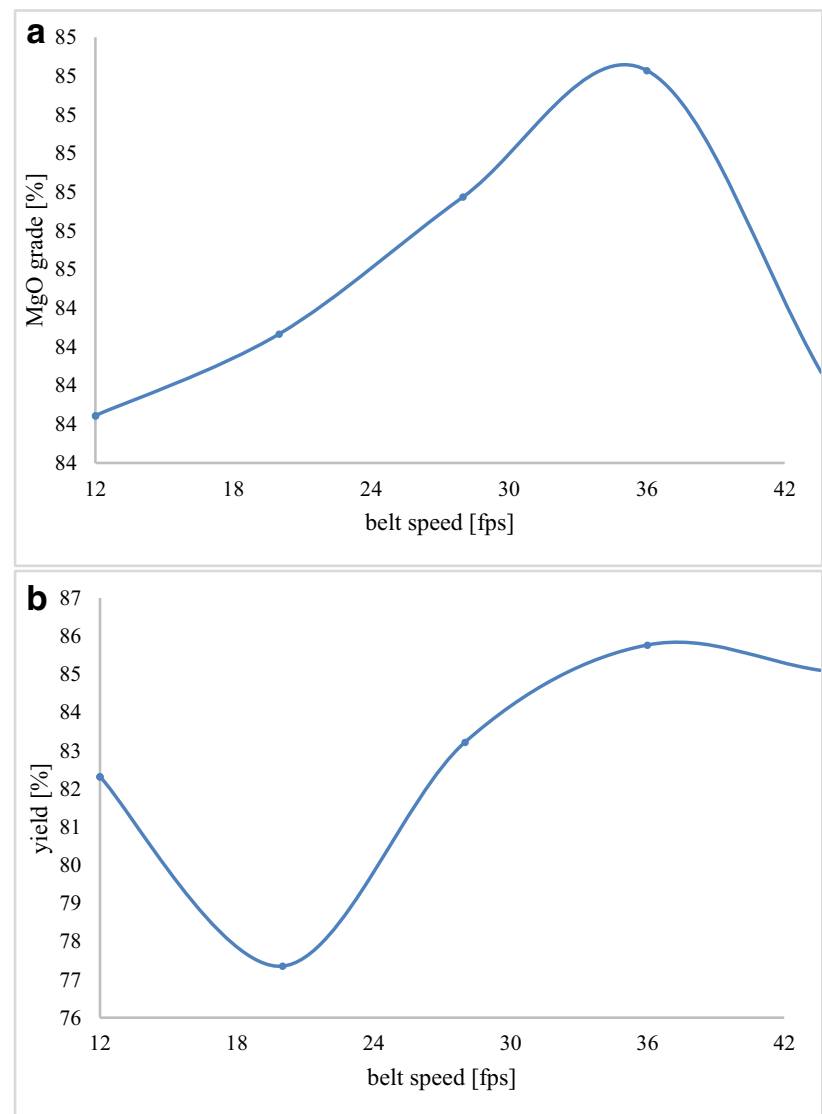

Fig. 8: a Influence of the belt speed on the MgO grade of the concentrate. b Influence of the belt speed on the MgO yield of the concentrate
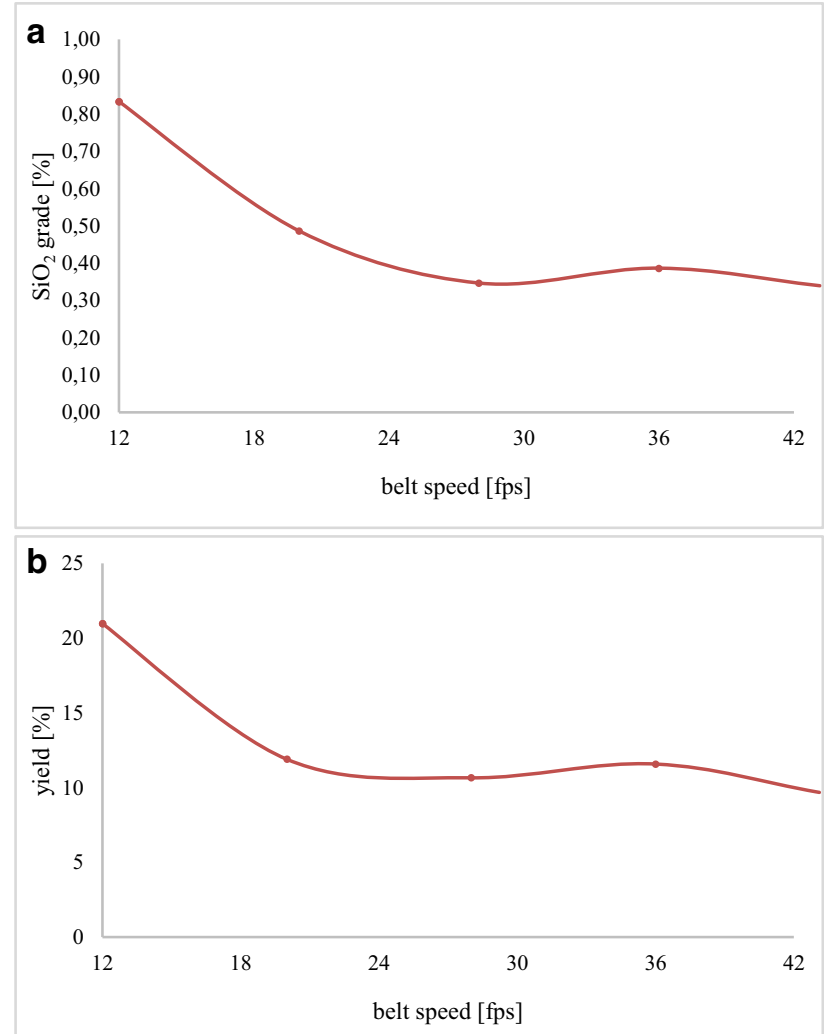

Fig. 9: a Influence of the belt speed on the $\mathrm{SiO}_{2}$ grade of the concentrate. b Influence of the belt speed on the $\mathrm{SiO}_{2}$ yield of the concentrate 

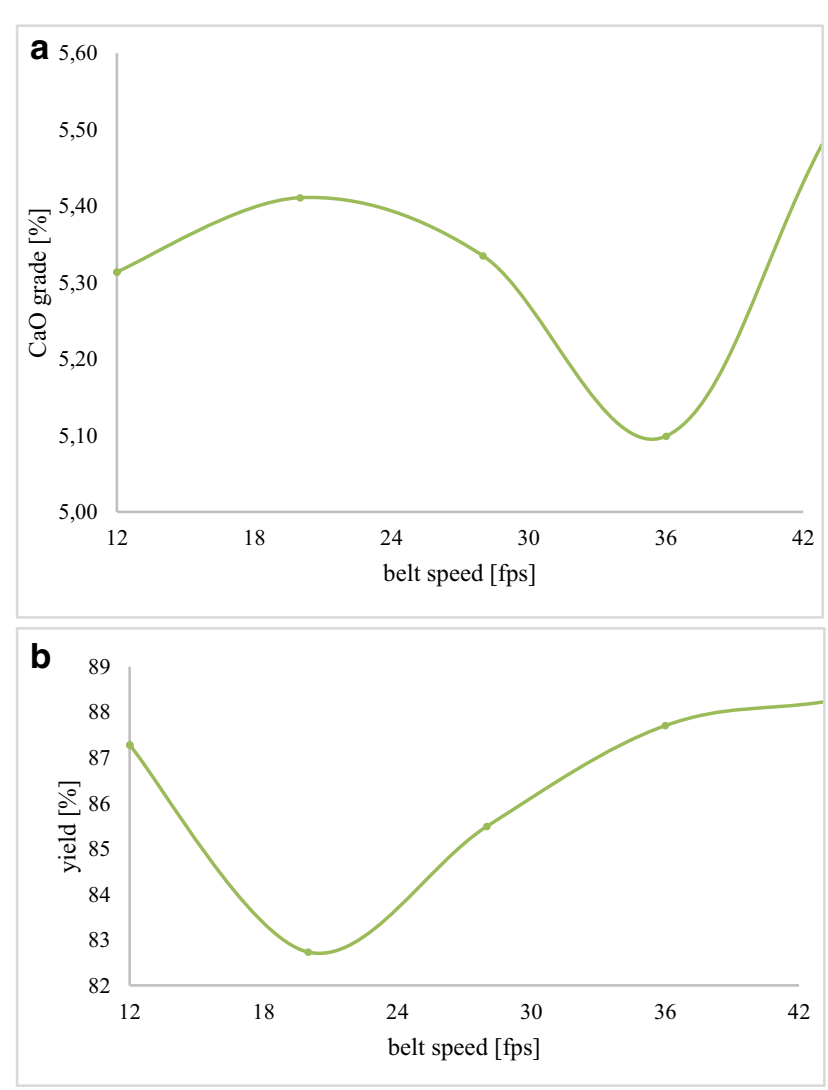

Fig. 10: a Influence of the belt speed on the $\mathrm{CaO}$ grade of the concentrate. b Influence of the belt speed on the $\mathrm{CaO}$ yield of the concentrate

\section{Summary}

The raw material characterization of the magnesium oxide sample showed that $\mathrm{MgO}$, in contrast to $\mathrm{CaO}$ and $\mathrm{SiO}_{2}$, accumulates in the fines.

From the first series of tests, the optimal machine settings were determined as follows:

a) applied voltage $-6 \mathrm{kV}$

b) electrode distance $-9 \mathrm{~mm}$

c) belt speed-36 fps $(11 \mathrm{~m} / \mathrm{s})$

d) polarity of the top electrode-positive

e) feed rate -5 (of 10)

For all further tests that do not relate to the optimization of the machine settings, these settings were used.

The investigation of the influence of the raw material temperature showed a clearly negative influence on the separation success by increasing the feed temperature.

The detailed examination of the belt speed gave an optimum at $36 \mathrm{fps}(11 \mathrm{~m} / \mathrm{s})$. At this peripheral speed of the belt, an $\mathrm{MgO}$ yield of $85.8 \%$ and a $\mathrm{MgO}$ grade of $85.0 \%$ in the concentrate.

\section{Conclusion}

The present study gives detailed information about the triboelectrostatic charging behaviour and the separateability by use of electrostatic separation of a specific magnesium oxide sample.

With the examined separation tests, an enrichment of $\mathrm{MgO}$ in the concentrate was possible. This fact identifies electrostatic separation as one dry processing method for the improvement of the product quality of caustic calcined magnesium oxide products.

To be able to make general statements about the triboelectrostatic charging behaviour of magnesium oxide, several samples with different amounts of accompanying components and different grain sizes will be analyzed in following studies.

Funding. Open access funding provided by Montanuniversität Leoben.

Open Access This article is distributed under the terms of the Creative Commons Attribution 4.0 International License (http://creativecommons. org/licenses/by/4.0/), which permits unrestricted use, distribution, and reproduction in any medium, provided you give appropriate credit to the original author(s) and the source, provide a link to the Creative Commons license, and indicate if changes were made.

\section{References}

1. Alvaradoa, E.; Torres-Martineza, L.M.; Fuentesa, A. F; Quintana, P. Preparation and characterization of $\mathrm{MgO}$ powders obtained from different magnesium salts and the mineral dolomite, Polyhedron, 19 (2000), iss. 22-23, November 2000, pp 2345-2351

2. Itatani, K.; Nomura, M.; Kishioka, A.; Kinoshita, M.; Mater, J.: Effect of starting particle size on hot-pressing of magnesium oxide powder prepared by vapour-phase oxidation process, Journal of Materials Science, 32 (1997), iss. 11, pp 2977-2984

3. Itatani, K.; Itoh, F.S.; Howell, A.; Kishioka, A.; Kinoshita, M.; Mater J.: Sintering of magnesium oxide powder prepared by vapourphase oxidation process-Relationship between particle size and mechanical properties of consolidated specimens, Journal of Materials Science, 31 (1996), iss. 10, pp 2757-2765

4. Heinrich, S.: Aufbereitung fester mineralischer Rohstoffe, Bd. 2: Sortierprozesse, 4. Aufl., Stuttgart: Deutscher Verlag für Grundstoffindustrie, 1996

5. Manouchehri, H.-R.: Triboelectric Charge Characteristics and Electrical Separation of Industrial Minerals, Doctoral thesis, Luleå Univ. of Technology, Department of Chemical and Metallurgical Engineering, 2000

6. Oberrauner, A.; Flachberger, H.: Beitrag zur Untersuchung der triboelektrischen Aufladecharakteristik feindisperser Körnerschwärme BHM Berg- und Hüttenmännische Monatshefte, 155 (2010), iss. 12, pp 565-570

7. Hrach, F.; Flynn, K.; Miranda, P.J.: Beneficiation of industrial minerals using a tribo-electrostatic belt separator, XXVIII International Mineral Processing Congress (IMPC) 2016, Quebec City, Canada: Canadian Institute of Mining Metallurgy and Petroleum (CIM), 2016

8. Siebertz, K.; Bebber, D.; Hochkirchen, T.: Statistische Versuchsplanung Design of Experiments (DoE), Berlin: Springer, 2010

Publisher's Note. Springer Nature remains neutral with regard to jurisdictional claims in published maps and institutional affiliations. 